\title{
IMPLEMENTING A LANDSCAPE APPROACH IN THE AGORO-AGU REGION OF UGANDA
}

\author{
James Omoding ${ }^{1 *}$, Gretchen Walters ${ }^{2 *}$, Salete Carvalho ${ }^{1}$, Marina Cracco ${ }^{2}$, \\ C.D. Langoya ${ }^{3}$, K. Gaster Kiyingi ${ }^{4}$, Chetan Kumar $^{1}$, Florian Reinhard ${ }^{1}$, Edward \\ Ssenyonjo ${ }^{5}$, Leo Twinomuhangi ${ }^{5}$
}

*Corresponding authors: James.Omoding@iucn.org; gretchen.walters@unil.ch

\author{
${ }^{1}$ International Union for Conservation of Nature, Kampala, Uganda; Gland, Switzerland; \\ Washington, DC, USA \\ ${ }^{2}$ Institute of Geography and Sustainability, Faculty of Geosciences and Environment, University \\ of Lausanne, Switzerland \\ ${ }^{3} \mathrm{JC}$ Holdings Ltd, Kampala, Uganda \\ ${ }^{4}$ Tree Talk Plus, Kampala, Uganda \\ ${ }^{5}$ Uganda National Forestry Authority, Kampala, Uganda
}

\section{ABSTRACT}

Landscape approaches are intended to resolve conflicts and address land and resource scarcity and competition. Often guided by 10 principles, numerous examples exist in the field but remain poorly documented. As a result, it remains difficult to learn about their implementation. This paper provides an example of the implementation of a landscape approach in a protected area landscape. We ask: How were landscape approach principles used in the implementation? What were the challenges and opportunities of using the landscape approach? We focus on the Agoro-Agu Landscape in the East Acholi area of Uganda. We find that some principles were critical for guiding the process, while others were outcomes of the landscape approach. Challenges included inadequate data, difficulties in addressing multiple planning units, limited resources to implement multi-stakeholder workshops, and politicisation of some issues. Opportunities included the mainstreaming of agreed actions into strategies and plans, increased resident capacity, conflict resolution, and clarified roles and responsibilities. Based on this example, landscape approaches may be used in future governmental projects.

Key words: Landscape approach, Agoro-Agu Central Forest Reserves, Agoro-Agu, East Acholi, conservation practice, Uganda, management, protected areas

\section{INTRODUCTION}

Historically, most game and forest reserves were established in the early 1900 s for colonial interests in natural resources when Uganda was under British colonial rule (Howard et al., 1997). Nature conservation was not the objective of protected areas (Petursson et al., 2013), and communities were excluded from resource use and decision-making (Anderson \& Grove, 1987). Centralised and decentralised conservation approaches to nature conservation (Hutton et al., 2005) and the inclusion of local people in the conservation policy process (Adams \& Hulme, 2001) emerged in the 1980 s and 1990s. Forest policy in Uganda followed a similar trend, with participatory approaches occurring in the last two decades (Turyahabwe \& Banana, 2008), including through a decentralisation policy and forest sector reform (Figure 1). Participatory processes were introduced for the following reasons: to recognise improvements in efficient management through cooperation with local communities, to reduce conflict, to reduce management costs, to commit to human rights, to support sustainable use, and to move towards decentralised forest management (Turyahabwe et al., 2012). These processes extend engagement with stakeholders to the landscape level.

Within Uganda's protected areas, protected forests fall under Central Forest Reserves (CFRs) managed by the National Forestry Authority (NFA), and Local Forest Reserves managed by the District Local Governments. All CFRs in the Agoro-Agu Management Plan Area in northern Uganda, the focus of this paper, are held and protected in trust for the people ${ }^{1}$. These areas have a hybrid form of governance involving the state and customary authorities (Kapidžić, 2018), with 93 per cent of lands in Acholiland under customary tenure (Hopewood, 2015). 




Figure 1. Timeline showing main events in forest and land policy in Uganda

Management of these areas is challenging due to conflict in the mid-1980s that displaced an estimated two million people (Roberts et al., 2008), disrupted health services and eroded traditional and family structures (Ministry of Health, 2005 in Chi et al., 2015). The legitimacy of customary leaders, or Rwot, is challenged by community members, including youth (Kobusingye, 2018). Acholiland is experiencing land disputes due to increasing land value, the rarity of permanent markers of land boundaries, lack of documents proving land ownership ${ }^{2}$ and complex socioeconomic, legal and political factors.

In 2018, the Agoro-Agu Landscape CFRs Management Plan in the Agoro-Agu sector and the Agoro-Agu Landscape Strategic Management Plan were due to be revised. In the past, the process only involved experts from forestry institutions. However, this approach had limited participation of stakeholders and an alternative, participatory approach was sought, in keeping with Uganda's trend towards participatory policy processes. At the encouragement of IUCN-Uganda, Uganda's NFA and the Forestry Sector Support Department of the Ministry of Water and Environment decided to use a landscape approach, a method which brings together stakeholders from different sectors to address a common issue at the landscape scale through decisionmaking processes (Reed et al., 2015). In contrast to the previous approach, using a landscape approach in the management plan revision process means that stakeholders are systematically included (Table 1). The implementation of the landscape approach in the Agoro -Agu Landscape is an attempt by the Government of Uganda to strengthen connectivity between the CFRs, community managed forests and agricultural lands through participatory dialogues that strengthen collaboration in forest resource management and improve livelihoods.
Implementation of a landscape approach is often guided by the paper 'Ten Principles for a Landscape Approach to Reconciling Agriculture, Conservation, and Other Competing Land Uses' (Sayer et al., 2013). These principles are:

- $\quad$ continual learning and adaptive management;

- $\quad$ common concern entry point;

- multiple scales;

- multi-functionality;

- $\quad$ multiple stakeholders;

- negotiated and transparent change logic;

- $\quad$ clarification of rights and responsibilities;

- $\quad$ participatory and user-friendly monitoring;

- $\quad$ resilience; and

- $\quad$ strengthened stakeholder capacity.

However, few landscape approaches are welldocumented (Reed et al., 2017), making it difficult to learn from and improve implementation. This paper documents the implementation of a landscape approach in a protected area landscape in Uganda, and its use in revising participatory management plans. We ask "How were the landscape approach principles used in the implementation? What were the challenges and opportunities of using the landscape approach?”

\section{CONTEXT AND BACKGROUND Study site}

The Agoro-Agu Landscape is located in northern Uganda and forms part of the Acholi subregion3 (Map 1), spanning the Lamwo, Pader, Kitgum and Agago districts in East Acholi. The northern border is bounded by South Sudan. The Acholi are the main ethnic group in the Agoro-Agu Landscape (Amone \& Muura, 2014). The 16 CFRs within the Agoro-Agu Landscape cover 65,548 ha under one Forest Management Planning Area, the Agoro-Agu Sector; these are managed with a common 
Table 1 Differences between Uganda's traditional planning process and the recently adopted landscape approach

\begin{tabular}{|c|c|c|}
\hline Steps & Traditional Practice & Landscape Approach \\
\hline $\begin{array}{l}\text { Step 1: Planning team } \\
\text { establishment }\end{array}$ & $\begin{array}{l}\text { Experts from the forestry } \\
\text { sector }\end{array}$ & $\begin{array}{l}\text { Forestry sector staff, private sector, Civil Society Organisations } \\
\text { (CSOs), Central Government staff, District Local Government } \\
\text { technical staff, political leaders, opinion leaders, etc. }\end{array}$ \\
\hline \multirow[t]{2}{*}{ Step 2: Data collection } & Within the Forest Reserve & $\begin{array}{l}\text { Considers entire landscape (district, sub-county, parish, village } \\
\text { levels), connectivity with agricultural land systems, wildlife } \\
\text { conservation areas, wetlands, other land use practices }\end{array}$ \\
\hline & $\begin{array}{l}\text { Meetings with Government } \\
\text { of Uganda officials }\end{array}$ & Multi stakeholders' dialogues and community meetings \\
\hline Step 3: Data processing & Internal & District technical staff, CSOs, political representatives are present \\
\hline Step 4: Drafting the plan & $\begin{array}{l}\text { Internal within Planning } \\
\text { Unit }\end{array}$ & $\begin{array}{l}\text { 'writeshop' with relevant stakeholders (District Technical staff, } \\
\text { CSOs, private sector, political representation) }\end{array}$ \\
\hline $\begin{array}{l}\text { Step 5: Planning } \\
\text { workshop and validation }\end{array}$ & Internal & Stakeholders invited to validation meeting \\
\hline Step 6: Final drafting & Internal & Peer reviews by partners, CSOs and private sector \\
\hline $\begin{array}{l}\text { Step 7: Plan final } \\
\text { validation and approval }\end{array}$ & $\begin{array}{l}\text { Limited stakeholder } \\
\text { engagement }\end{array}$ & $\begin{array}{l}\text { Pre-requisite to involve other stakeholders such as the District } \\
\text { Councils }\end{array}$ \\
\hline $\begin{array}{l}\text { Step 8: Plan } \\
\text { implementation }\end{array}$ & Responsible body & All stakeholders have a role to play \\
\hline $\begin{array}{l}\text { Step 9: Plan monitoring } \\
\text { and revision }\end{array}$ & Internal & $\begin{array}{l}\text { Participatory, joint monitoring based on a monitoring and } \\
\text { evaluation plan }\end{array}$ \\
\hline
\end{tabular}


Map 1. The Agoro-Agu Landscape 


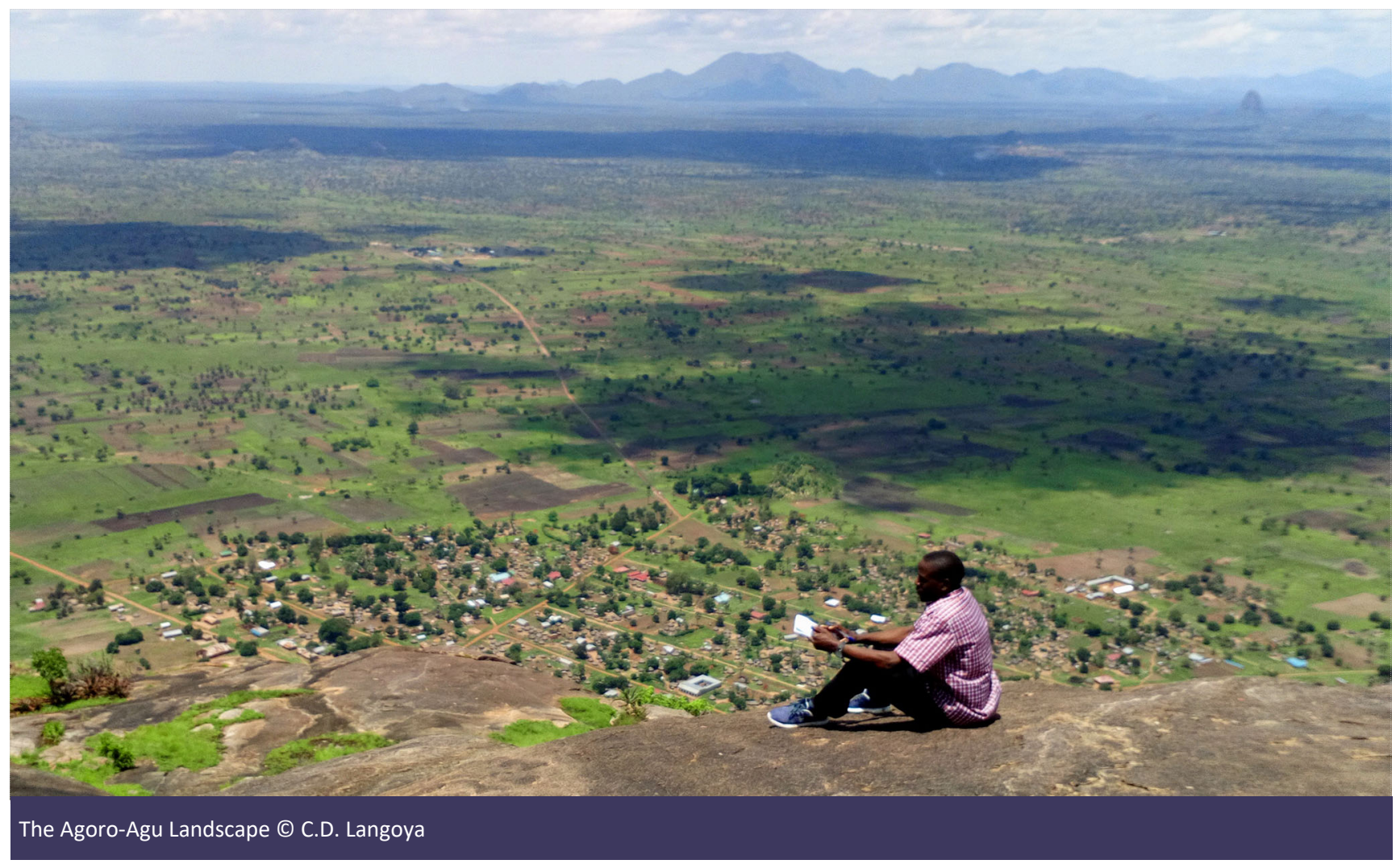

Forest Management Plan (Republic of Uganda, 2019). The three main land use types in the Agoro-Agu Sector are small-scale cultivation (37.5 per cent), grassland (12.5 per cent) and woodland (43.8 per cent).

Uganda is a biodiverse country with 1,742 terrestrial vertebrate species (Plumptre et al., 2019), 4,816 plant species (Luke \& Beentje, 2016 in Kalema et al., 2016), 1,300 species of butterflies and 260 dragonfly species (Plumptre et al., 2019). There are two Key Biodiversity Areas (Ogili and Nyangea-Napore Forest Reserves) (Plumptre et al., 2019) in the landscape. The vegetation of the Agoro-Agu Landscape includes Afromontane forests, shrublands, woody grasslands and bamboo (Zhao et al., 2018). Protected areas covering four per cent of the Agoro-Agu Landscape shelter an estimated 95 per cent of the animal and plant species (Gizachew, 2018). The Agoro-Agu CFR is one of the top 20 Forest Reserves for species richness in Uganda (Howard et al., 2000).

Uganda lost half of its overall biodiversity value from 1975 to 1995 (Pomeroy et al., 2017) due to habitat loss, agricultural encroachment and expansion, climate change effects, over-harvesting of resources, among others. In the Agoro-Agu CFR and its adjacent area, forest and woodland underwent progressive cover changes to bare land, with more pronounced changes between 2001 and 2010 (Obegiu, 2012).

\section{Landscape approach method}

Following the landscape approach principles, the project team sought a common concern entry point: balancing the competing interests in the landscape. The implementation process of the landscape approach included four overarching elements, detailed below.

\section{Establishing and training a Core Planning Team}

The project team, working with the NFA and Forestry Sector Support Department Managers, identified key stakeholders at the national, regional and local level and from public and private institutions and civil society. These stakeholders nominated representatives that constituted the Core Planning Team and included representatives from the Forest Sector Support Department, NFA, Uganda Wildlife Authority, and District Local Government (political and technical leaders including the District Planner, District Physical Planner, District Community Development Officer, District Forestry Officer, District Natural Resources Officer, and Secretary for Production). To build confidence and trust in the selected members, chosen for their skills in landscape planning, the project team organised an orientation meeting to introduce them to the forest and landscape management planning guidelines, the general approach to be used, and training on participatory rural appraisal tools. 
Gathering primary and secondary data, problem identification and prioritisation

The Core Planning Team collected landscape data (biophysical, social and economic). They also raised awareness about the need for joint planning (to identify issues, priorities, actions) and led stakeholder consultations and dialogues from district to village level using the skills acquired during the orientation workshop.

Activities included building a landscape planning knowledge base, conducting land use planning analysis (with participatory rural appraisal and geographical information system), completing a social and strategic environmental assessment, and understanding the spatial-temporal changes. We designed a number of tools prior to field data collection including interview guides, focus group discussions, presentations to district and sub-county level meetings, planning matrices for environment action planning and forest resources evaluation and valuation matrix, timeline for tracking historical trends, and resource maps for each district.

Developing actions based on an established vision With stakeholders, we tried to establish what the future of the landscape should look like and identify what needed to change to achieve that vision. At the District Local Government level, stakeholder engagement and dialogues were conducted for each district. The identification of participants was done in collaboration with District Local Government officials and members of the Core Planning Team. At the sub-county level (also known as Lower Local Government), consultations involved parish chiefs, cultural leaders and CSO

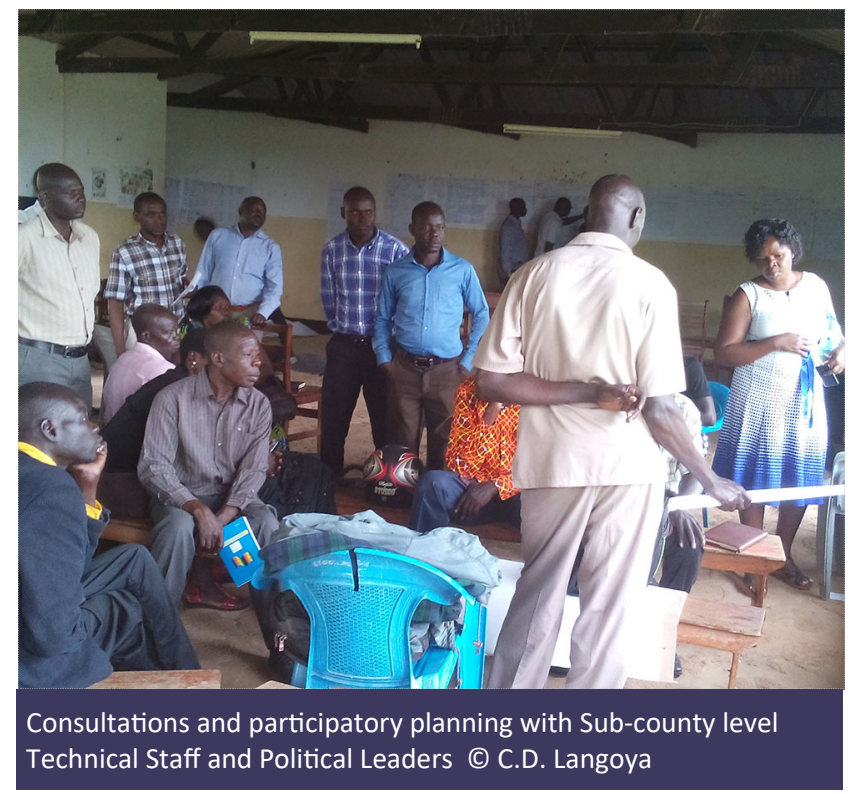

representatives. For all these meetings, the Forest Sector Support Department, NFA and Uganda Wildlife Authority were represented. The process included consultations with the Aswa River Hydro Power Project, the Apirit Border Post and Revenue Collection Point, the Agoro Irrigation Project, the Palabek Refugee Settlement, individual tree growers, Collaborative Forest Management, and Community Forest Groups.

\section{Development and validation of the Forest and} Landscape Management Plans

The final stage encompassed the development of the management plan through a 'writeshop'4. The writeshop brought together members of the Core Planning Team to write the management plans based on the data collected. The team built options, analysed the desired future change, and developed projects for change.

The process led to the development and validation of two complementary plans for the landscape (the CFRs Management Plan and the Agoro-Agu Landscape Strategic Management Plan for areas outside the CFRs) based on the Government of Uganda legislative framework on protected areas.

Approval of Forest and Landscape Management Plans: The NFA Board of Trustees and the Minister of Water and Environment approved the CFRs Management Plan. All four District Local Government Councils of East Acholi approved the Landscape Management Plan and agreed to integrate the priority actions in the Landscape Management Plan into their District Development Plans and budgets.

\section{IMPLEMENTING THE LANDSCAPE APPROACH Adoption of the landscape approach principles}

The adopted landscape approach used many of the ten aforementioned principles. Here, we emphasise the principles such as Adaptive Management, Resilience, Multiple Scales and Multifunctionality that were the most important for guiding the process. Other principles were outcomes of the process and are not discussed in detail. Adaptive management resulted from the shift from exclusive planning at the site level to participatory planning at the landscape level. This landscape level planning resulted in a multi-scalar process across multifunctional landscape units, leaving a more resilient landscape. The resulting approach was supported by the local communities. We document this process elsewhere, where we focused on monitoring perceptions of landscape governance (IUCN, 2020).

\section{Common concern entry point}

The common concern entry points included addressing poverty, food security, climate change, water scarcity, 
deforestation and loss of biodiversity at the local level. Balancing the competing interests of different stakeholders in the Agoro-Agu Landscape was of paramount importance in order to: (i) protect, restore and promote sustainable use of protected areas and ecosystems; (ii) ensure availability of forest products and services (for current and future generations); (iii) promote inclusive and sustainable economic growth and development; (iv) ensure food supplies through sustainable agriculture; and (v) combat climate change and its impacts.

\section{Multiple stakeholders and negotiated and transparent logic chain}

The Core Planning Team included representatives of many stakeholder groups. Throughout the process, the project team engaged forest-adjacent communities in discussing issues in the landscape and specific issues related to the forest reserves. The team used consultation and information approaches to inform the communities about the landscape approach and why it was needed. This provided an opportunity for participants to engage from an informed point of view. Engagement with existing platforms in Lamwo District, such as the Agoro-Agu Forest Landscape Platform, helped identify critical issues across the districts that needed joint planning across the landscape. The development and use of the platform demonstrates the long-term involvement of multiple stakeholders in the landscape. The platform includes District Local Governments, Line Government Ministries, Departments and Agencies, CSOs, public sector organisations, cultural institutions, faith-based organisations, academic and research institutions, and community groups such as Collaborative Forest Management Associations.

At the District Local Government level, the team conducted stakeholder engagement and land use dialogues and meetings in each district. The project team, in collaboration with District Local Government officials, identified participants. At the sub-county level (e.g. Lower Local Government), consultations involved parish chiefs, cultural leaders and CSO representatives. For all these meetings, the Forest Sector Support Department, NFA and Uganda Wildlife Authority were represented. The team consulted with private sector partners, such as those working in energy, irrigation and plantations.

Four district level meetings and 42 sub-county level meetings were conducted and 68 people attended the validation meeting. Out of these 68 people, 16 per cent were elected officials, 15 per cent were CSOs/NGOs/ private sector representatives, and 24 per cent were women leaders.

\section{Clarification of rights and responsibilities}

This principle was considered important due to the challenges in the region over land rights. The team conceived a governance framework and delivery mechanism for the plan. Key stakeholders were identified and their roles, including the role of the Agoro -Agu Forest Landscape Platform, were developed. Stakeholders' roles included the following: 1) NFA holds a leading role in the Core Planning Team and provides expertise on forestry, leads the comprehensive consultations with District and Sub-county leaderships and communities neighbouring the CFRs, and implements the Forest Management Plan in collaboration with other actors; 2) The Higher District Local Governments (Districts) manage the collaboration at the sub-national level and ensure the integration of outputs into the District Development Plans and budgets for sustainability; 3) The Lower District Local Governments (sub-county and parish level) manage the collaboration at the community level and ensure the integration of outputs into the Sub-county and Parish Development Plans to create ownership and sustainability at grassroots level; 4) The private sector provides expertise and guides the planning process in relation to economic enterprises; and 5) The CSOs have a representative in the Core Planning Team and provide outputs to civil society networks.

\section{Participatory and user-friendly monitoring}

The Agoro-Agu Forest Landscape Platform includes a set of targets to achieve a shared goal and objectives, and a participatory engagement plan to work towards the targets. For example, the Agoro-Agu Landscape Strategic Management Plan includes a section on monitoring with defined roles and tasks for stakeholders.

The plan's objectives include: (i) to keep planned activities on track and monitor what has been achieved; (ii) to ensure that the planned activities are carried out by those identified; (iii) to reflect critically on progress and facilitate adaptive management based on lessons learnt, generating ideas for making improvements; (iv) To provide information on the social, economic and environmental impacts as a result of implementing the planned activities. The system was developed in harmony with other schemes for monitoring district level plans; therefore, it is compliant with and will operate through decentralised implementation service delivery reforms and the sectoral programme development policies of the Government of Uganda. 
Monitoring occurs on a continual basis. The implementation of this plan will be evaluated annually and at the end of the plan. Annual evaluations will assess performance and provide the opportunity to reflect on the gaps and suggest improvements.

\section{Strengthened stakeholder capacity}

Creation of resident capacity initially happened within the government institutions and CSOs that were part of the Core Planning Team. These stakeholders were trained and participated in the planning process from its inception to its end. The 45 Core Planning Team participants were trained in forest management planning using a landscape approach, dialogues, data collection and collation (based on data collection tools). During the management planning process, the stakeholders agreed to expand and strengthen the Agoro-Agu Forest Landscape Platform beyond the Lamwo District to cover the Districts of Kitgum, Pader and Agago. This is intended to operationalise the landscape management approach and to ensure a coordinated management approach for NFA managed CFRs, Forestry Sector Support Department and District Local Government managed Local Forest Reserves, community managed forests, wildlife migratory corridors, agricultural lands and other fragile ecosystems. This will occur through dialogues that resolve conflicts over natural resource access rights and will strengthen community-based natural resource management. The Agoro-Agu Forest Landscape Platform developed a Memorandum of Principles to provide for governance, membership, co-ordination and operation of the platform; it includes a General Assembly comprising all members of the platform, a Steering Committee and a Secretariat.

\section{Challenges and opportunities}

We observed the following challenges:

Limited resources: Given the need for detailed consultations and planning with multiple stakeholders and at different scales and levels, commensurate resources are required. The landscape approach needs time and the appropriate implementation and uptake at each level and by many institutions. For example, in Uganda, obtaining the four District Council's Resolutions for the Landscape Management Plan approval process may take six steps. Many levels are consulted for approval, and debates are required to develop and approve reports at each stage. In most instances, the NFA representative, Forestry Sector Support Department and project leaders must be present at key Council meetings.

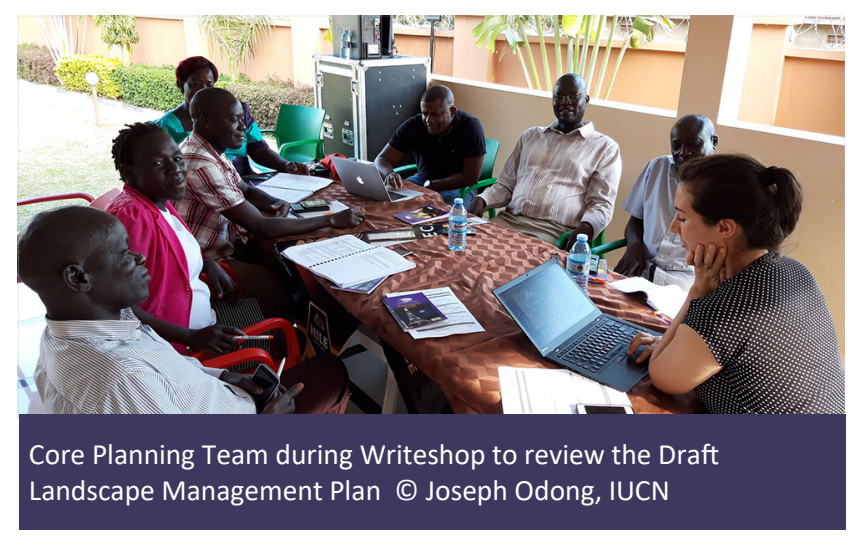

Inadequate data: Spatial data for the landscape is insufficient or lacks the required quality, limiting analysis.

Complexity addressing multiple planning units: Fragmentation of the landscape into small administrative units complicates the planning process, increasing coordination time. Each unit demands and has the right to know its obligation, mandate and contribution.

Politicisation: Politicisation around issues (e.g. encroachment, boundary conflicts) distorts consensus building, creating unnecessary delays. For example, activities intended to resolve protected area encroachment may be used by some politicians to criticise authorities and discredit an opponent participating in the process by suggesting that the approach promotes land grabbing. Politicisation frequency is increasing due to Uganda's upcoming national elections in 2021.

Benefits and opportunities observed during the application and adoption of the landscape approach include:

Case for learning: The process followed throughout the landscape approach demonstrates how to build capacity and strengthen institutions in forest management planning, which can then be used for implementation elsewhere in Uganda. The landscape approach may help in the review process of the Uganda Forestry Conservation Master Plan.

Stronger resident capacity: The landscape approach fosters the creation of resident capacity within local government, CSOs, local political leaders and the community. The Agoro-Agu Forest Landscape Platform offers a forum for stakeholders to share an understanding of landscape issues, agree on the intersectoral linkages and create synergies for strategic 
interventions that enhance positive change in community livelihoods and ecosystem integrity. The platform also provides space for stakeholders to coordinate and jointly engage in lobbying, advocacy and fund raising with a collective voice and provides the members with opportunities for capacity building through peer learning and information sharing.

Conflict resolution: The landscape approach created an opportunity to resolve conflicts (encroachment, boundary challenges, etc.) and an opportunity to clarify cross-sectoral and trans-boundary issues. For example, encroachment into protected areas creates conflict between management authorities and encroachers. GPS technology was used to clarify boundaries, areas of encroachment and community lands. Most District Councils of the Agoro-Agu Landscape are in agreement with swapping encroached forest areas with intact, forested areas. It is a long process, but once completed, will reduce conflict.

Mainstreaming of agreed actions into strategies and plans: The landscape approach strengthens natural resources management at the sub-national level through the inclusion of proposed actions into the District Development Plans for implementation. Most District Councils have passed resolutions to integrate priority actions into their Development Plans and budgets.

Clarity on mandates, roles and responsibilities: The stakeholders became aware of mandates, roles and responsibilities.

Co-development of proposals: The landscape approach process supports the co-development of proposals for joint monitoring and evaluation, law enforcement, governance and trade.

Higher landscape connectivity: The adoption of the principles provides the opportunity to create connectivity between protected areas, agricultural lands and other areas.

\section{CONCLUSION}

The implementation of the landscape approach in the Agoro-Agu Landscape was possible because of the interest of the Government of Uganda to use more participatory tools for landscape planning. This, in turn, helped bring all stakeholders to the table. Select principles guided the process that culminated in the creation of two plans for the landscape. One plan, the Integrated Landscape Management Plan, contributes to the achievement of a variety of governmental policies and internationally ratified treaties, conventions and agreements to which Uganda is a signatory. As a strategic document, this Integrated Plan represents a paradigm shift from sectoral forest management planning to an integrated approach. Another relevant result includes the Agoro-Agu Forest Landscape Platform that was instituted to foster multi-stakeholder arrangements.

In addition to offering a learning case, the benefits and opportunities observed throughout the application of the landscape approach principles include mainstreaming agreed actions into strategies and plans, increased resident capacity, conflict resolution, definition and clarity on mandates, roles and responsibilities, higher landscape connectivity and opportunities for policy influence.

The application of the principles also revealed some challenges, namely, inadequate quantity and quality of data, complexity addressing multiple planning units, limited resources to implement the required workshops, and issue politicisation. Despite the amount of time and resources required to implement a landscape approach in this context, the resulting participatory process supported by many stakeholders is significant. We hope that bringing awareness to these challenges will help other researchers and practitioners to improve the application of the landscape approach.

\section{ENDNOTES}

${ }^{1 .}$ As stipulated by article 237(2) (b) of the Constitution of the Republic of Uganda, 1995.

2. Before the Land Act of 1998, there was no requirement or legal procedure in place to register customary land.

${ }^{3}$.In this paper, we use the name 'Agoro-Agu Landscape', as used by the National Forestry Authority (NFA) and how it is referred to in all Government documents. It is also called the East Acholi landscape by the local community, with Agoro-Agu being the largest CFR located in Lamwo District and, from which, NFA derives the official name of the landscape.

${ }^{4} \mathrm{~A}$ writeshop is an intensive process bringing together relevant stakeholders and publishing specialists to produce a publication in a short time.

\section{CONFLICT OF INTEREST}

None.

\section{ACKNOWLEDGEMENTS}

The authors thank all the people who took part in the "Stabilizing Land Use: Protected Areas Categories V and VI as Landscape Mechanisms for Enhancing Biodiversity in Agricultural Land, Ecological Connectivity and REDD+ Implementation" project in Uganda for providing information, feedback, time and knowledge. They include the Executive Director and the 
Director of Policy and Planning (NFA) and the Commissioner for Forestry (Ministry of Water and Environment); the Core Planning Team led by JC Holdings Ltd Consultants; the local community in the districts of Pader, Kitgum, Agago and Lamwo; the representatives of the private sector, CSOs and NGOs; the Plan's peer reviewers and participants engaged in the validation process; and the District Local Governments, political leaders and technical staff of the four districts. We thank two anonymous reviewers and the Editor of Parks for their comments. This project was funded by the German Federal Ministry for the Environment, Nature Conservation and Nuclear Safety (BMUB).

\section{ABOUT THE AUTHORS}

Salete Carvalho is a geographer and GIS analyst who works in the domain of environmental science. Previously, Salete worked as a GIS and data analyst for IUCN in Switzerland, on forest landscape restoration, ecosystem services and project monitoring and evaluation. She holds a Degree in Geography and Spatial Planning and a Master's in Disaster Risk Management from the University of Porto, Portugal, where she also worked as a scientific collaborator in the field of forest fires. Currently Salete is focusing on mainstreaming the ecosystem service approach into decision-making planning.

Marina Cracco is an associate researcher at the University of Lausanne. Her expertise and interests lie at the interface between environment and evaluation, and in the use and development of tools and mixed methods that can help society to evaluate biodiversity conservation programmes and projects to improve the evidence base for decision-making. Her work and research focus on monitoring and evaluation of environmental projects, protected area management effectiveness, ecosystem-based approaches, and impact evaluation design. She is a member of IUCN's WCPA, CEM, and a member of the IUCN World Heritage Panel. She holds a Master's degree in sustainable development and conservation biology from the University of Maryland.

Gaster Kiyingi is a knowledge management and communications Specialist, holding an M.Sc. in Geographic Information Systems, a B.Sc. in Natural Resource Management and a Postgraduate Diploma in mass communications. He has over 25 years' experience in the forestry, water and environment sectors. His recent engagements include environment management for the oil sector, integrated water development and management planning, bio-diversity and ecosystem restoration, impacts and implications of agrocommodities (sugarcane, oil palm, tobacco, coffee, tea) on the environment, Reduction of Emissions from Deforestation and forest Degradation (REDD+), and engagements on climate change related vulnerabilities to determine climate actions.

Chetan Kumar is Senior Program Coordinator with the Forest Conservation Program of IUCN, based in Washington, DC. He has a strong track record for conducting and managing interdisciplinary research programmes on environment and development issues focused on promoting understanding and practical application of research on important issues in the forestry sector. He has previously held positions at the DFID, the University of Cambridge, the UNEP-WCMC, CIFOR and TERI. He holds a Master's in Forestry Management (India), an MPhil, and a Ph.D. in Geography from the University of Cambridge (UK).

Council Dickson Langoya is a Forestry Resources, Environmental and Natural Resources Planning and Management specialist with over 25 years' experience. He holds a BSc. Forestry Degree from Makerere University Kampala and an MSc. in Rural Environment Management from University of Aberdeen-Scotland. He worked as a civil servant in Uganda before becoming a consultant; he has worked with the FAO, UNDP, IUCN, USAID and AfDB/NDF. He is interested in promoting enterprise-based natural resource management and the way in which public and community participation address social, economic and environmental concerns.

James Omoding is a Senior Programme Officer with the IUCN Uganda Country Office. He previously worked for the Uganda Wildlife Authority on Community Conservation and Protected Area Planning. James has over 20 years' experience in participatory approaches, biodiversity conservation and protected area management. A zoologist and botanist by training, with an MSc from Makerere University, Uganda, he values and practises interdisciplinary and participatory approaches to protected areas, natural resources planning and management. His current area of focus is landscape approaches, governance, including facilitating the establishment and strengthening of multistakeholder platforms for landscapes' improved governance.

Florian Reinhard is a geographer and holds a master's degree from the University of Lyon II. Since 2016, Florian has worked for IUCN where he leads some of the work on monitoring, evaluation and learning for the Forest Conservation Programme and the Nature- 
based Solution group. Prior to joining IUCN, Florian managed several multi-disciplinary projects in Burkina Faso and Tanzania. Some of the domains he worked on include the participative management of village land use, the establishment and management of protected areas, the development of value chains for non-timber forest products and capacity building of communitybased organisations.

Edward Ssenyonjo is a forester by profession with a MSc. from Makerere University. He has 16 years of working experience with remote sensing and GIS for natural resource management at the NFA where he is the Coordinator of Inventory and Surveys. He has trained staff in several institutions and projects. He has worked on several special assignments including assessing environmental impacts by large-scale infrastructure projects including the oil and gas sector, forest landscape restoration and ecosystem sensitivity mapping. $\mathrm{He}$ is active in national REDD+ activities, Green House Gas inventories and Natural Capital Accounting.

Leo Twinomuhangi is a Coordinator of Policy and Planning at the National Forestry Authority in Uganda. $\mathrm{He}$ aligns development and implementation of Strategic, Operational and Forest Management Plans with national development. Leo holds an MSc and BSc in Forestry from Makerere University with graduate training in strategic planning and management. As a Forestry Manager for 15 years, Leo developed expertise in forest-landscape planning, biodiversity off-sets, catchment-restoration, certification, law-enforcement governance and collaborative resource managementplanning. Leo is interested in the valuation of protected area resources that transform the role of beneficiaries and account for sustainable management of degraded landscapes.

Gretchen Walters is a professor of conservation practice at the University of Lausanne. She previously worked for IUCN in Central and West Africa, and Switzerland, on landscape approaches, natural resource governance, cultural landscapes and protected areas. She is an anthropologist and botanist, and takes an interdisciplinary and transdisciplinary approach to conservation research and practice. She holds a $\mathrm{PhD}$ from the University College London. She is a member of IUCN's WCPA, CEESP, SSC and SuLi, and is an Honorary Member of the ICCA Consortium. Her research currently focuses on landscape governance and the historical ecology of conservation landscapes.

\section{REFERENCES}

Adams, W.M. and Hulme, D. (2001). 'If community conservation is the answer in Africa, what is the question?' Oryx 35: 193-200. [https://doi.org/10.1046/j.1365-3008.2001.00183.x]

Amone, C. and Muura, O. (2014). 'British colonialism and the creation of Acholi ethnic identity in Uganda, 1894 to 1962.' The Journal of Imperial and Commonwealth History 42: 239257. [https://doi.org/10.1080/03086534.2013.851844]

Anderson, D. and Grove, R. (1987). The scramble for Eden: Past, present, and future in African conservation. In: Conservation in Africa: People, Policies, and Practice. Cambridge: Cambridge University Press.

Chi, P.C., Bulage, P., Urdal, H. and Sundby, J. (2015). 'A qualitative study exploring the determinants of maternal health service uptake in post-conflict Burundi and Northern Uganda.' BMC Pregnancy and Childbirth, 15: 18. [doi:10.1186/s12884015-0449-8]

Gizachew, B., Solber, S. and Puliti, S. (2018). 'Forest carbon gain and loss in protected areas of Uganda: Implications to carbon benefits of conservation.' Land 7: 138. [doi:10.3390/ land7040138]

Hopewood, J. (2015). 'Women's land claims in the Acholi Region of Northern Uganda: What can be learned from what is contested.' International Journal on Minority and Group Rights 22: 387-409. [https://doi.org/10.1163/15718115-02203005]

Howard, P., Davenport, T. and Kigenyi, F. (1997). 'Planning conservation areas in Uganda's natural forests.' Oryx 31: 253 -264. [https://doi.org/10.1046/j.1365-3008.1997.d01-124.x]

Howard, P., Davenport, T., Kigenyi, F.W., Viskanic, P., Baltzer, M., Dickinson, C., Lwanga, J., Matthews, R. and Mupada, E. (2000). 'Protected area planning in the tropics: Uganda's national system of forest nature reserves'. Conservation Biology 14: 858-875. [https://doi.org/10.1046/j.15231739.2000.99180.x]

Hutton, J., Adams, W.M. and Murombedzi, J.C. (2005). 'Back to the barriers? Changing narratives in biodiversity conservation'. Forum for Development Studies 32: 341-370. [https://doi.org/10.1080/08039410.2005.9666319]

IUCN. (2020). 'Making sense of community natural resource governance perceptions: Learning from results of a social survey tool called SenseMaker ${ }^{\circledR}$ in support of natural resource landscape governance in Uganda'. Forest Brief 26. [https://www.iucn.org/sites/dev/files/content/ documents/20200417_plus-ugandasensemaker_fbrief_final.pdf]

Kalema, J., Namaganda, M. Bbosa, G. and Ogwal-Okeng, J. (2016). 'Diversity and status of carnivorous plants in Uganda: Towards identification of sites most critical for their conservation.' Biodiversity Conservation 25: 2035-2053. [doi 10.1007/s10531-016-1177-8]

Kapidžić, D. (2018). Public authority beyond hybrid governance: Creating throughput legitimacy in Northern Uganda. Peacebuilding, 6(2): 127-143. [doi: 10.1080/21647259.2018.1449187]

Kobusingye, D.N. (2018). 'African youths: The forgotten category in land governance. A case study of post-conflict Acholi Region, Northern Uganda.' Geoforum.[https://doi.org/10.1016/ j.geoforum.2018.06.008]

Luke, Q. and Beentje H. (2016). 'African floras: Coverage and uses'. In: Kalema, J., Namaganda, M. Bbosa, G. and OgwalOkeng, J. (2016). 'Diversity and status of carnivorous plants in 
Uganda: Towards identification of sites most critical for their conservation.' Biodiversity Conservation 25: 2035-2053. [doi 10.1007/s10531-016-1177-8].

Obegiu, L. (2012). 'Impact of human disturbances on woody species diversity, structure and land cover change in and adjacent to Agoro Agu Central Forest Reserve, Uganda'. Master's degree, Makerere University. [http:// makir.mak.ac.ug/handle/10570/2103].

Petursson, J.G., Vedeld, P. and Marieke, S. (2013). 'An institutional analysis of deforestation processes in protected areas: The case of the transboundary Mt. Elgon, Uganda and Kenya'. Forest Policy and Economics 26 (January): 22-33. [https://doi.org/10.1016/j.forpol.2012.09.012].

Plumptre, A.J., Ayebare, S., Behangana, M., Forrest, T.G., Hatanga, P., Kabuye, C., Kirunda, B., Kityo, R., Mugabe, H., Namaganda, M., Nampindo, S., Nangendo, G., Nkuutu, D.N., Pomeroy, D., Tushabe, H. and Prinsloo, S. (2019). 'Conservation of vertebrates and plants in Uganda: Identifying Key Biodiversity Areas and other sites of national importance'. Conservation Science and Practice 1, e7. [https://doi.org/10.1111/csp2.7]

Pomeroy, D., Tushabe, H. and Loh, J. (2017). The State of Uganda's Biodiversity 2017. National Biodiversity Data Bank Department of Environment Management, College of Agricultural and Environmental Sciences, Makerere University. [http://www.natureuganda.org/downloads/ presentations/BDpercent202017per cent20Indicatorsper cent20Report.pdf]

Reed, J., Deakin, L. and Sunderland, T. (2015). 'What are "Integrated Landscape Approaches" and how effectively have they been implemented in the tropics: A systematic map protocol'. Environmental Evidence 4 (1): 2. [https:// doi.org/10.1186/2047-2382-4-2]

Reed, J., van Vianen, J., Barlow, J. and Sunderland, T. (2017). 'Have integrated landscape approaches reconciled societal and environmental issues in the tropics?' Land Use Policy 63 (April): 481-492. [https://doi.org/10.1016/ j.landusepol.2017.02.021]
Republic of Uganda, Ministry of Health (2005). Health and mortality survey among internally displaced persons in Gulu, Kitgum and Pader districts, Northern Uganda. Kampala: $\mathrm{MoH}$ \& WHO.

Republic of Uganda, National Forestry Authority (2019). Surrender Illegal Land Titles in Central Forest Reserves. Notice, Kampala, 19 February 2019. [https://www.nfa.org.ug/ index.php/12-nfa-news/138-surrender-illigal-land-titles-incentral-forest-reserves-2] (Accessed: May 2020)

Roberts, B., Guy, S., Sondorp, E. and Lee-Jones, L. (2008). 'A basic package of health services for post-conflict countries: Implications for sexual and reproductive health services'. Reproductive Health Matters. 16(31): 57-64. [10.1016/S09688080(08)31347-0]

Sayer, J., Sunderland, T., Ghazoul, J., Pfund, J.-L., Sheil, D., Meijaard, E., Venter, M., Boedhihartono, A.K., Day, M., Garcia, C., van Oosten, C. and Buck, L.E. (2013). 'Ten principles for a landscape approach to reconciling agriculture, conservation, and other competing land uses.' Proceedings of the National Academy of Sciences 110: 8349-8356. [https:// doi.org/10.1073/pnas.1210595110]

Turyahabwe, N. and Banana, A.Y. (2008). 'An overview of history and development of forest policy and legislation in Uganda'. International Forestry Review 10(4): 641-656. [https:// doi.org/10.1505/ifor.10.4.641].

Turyahabwe, N., Agea, J.G., Tweheyo, M. and Balaba Tumwebaze, S. (2012). 'Collaborative forest management in Uganda: Benefits, implementation challenges and future directions'. Sustainable Forest Management - Case Studies. [https://doi.org/10.5772/28906]

Zhao, Y., Feng, D., Jayaraman, D., Belay, D., Sebrala, H., Ngugi, J., Maina, E., Akombo, R., Otuoma, J., Mutyaba, J., Kissa, S., Qi, S., Assefa, F., Oduor, N.M., Ndawula, A.K., Li, Y. and Gong, P. (2018). 'Bamboo mapping of Ethiopia, Kenya and Uganda for the year 2016 using multi-temporal Landsat 


\section{RESUMEN}

Los enfoques basados en el paisaje tienen por objeto resolver conflictos y abordar la escasez de tierras y recursos y la competencia. A menudo guiados por 10 principios, existen numerosos ejemplos sobre el terreno pero se hallan mal documentados. En consecuencia, sigue siendo difícil obtener información acerca de su implementación. En el presente documento se ofrece un ejemplo de la implementación de un enfoque basado en el paisaje en una zona protegida. Nos preguntamos: ¿Cómo se utilizaron los principios del enfoque basado en el paisaje en la implementación? ¿Cuáles fueron los desafíos y oportunidades relacionados con la utilización del enfoque basado en el paisaje? Nos centramos en el paisaje Agoro-Agu en la región oriental de Acholi en Uganda. Consideramos que algunos principios fueron fundamentales para orientar el proceso, mientras que otros fueron resultados del enfoque basado en el paisaje. Entre los problemas que se plantearon cabe mencionar la insuficiencia de datos, las dificultades para abordar las múltiples dependencias de planificación, los recursos limitados para llevar a cabo talleres con múltiples interesados y la politización de algunas cuestiones. Las oportunidades incluyeron la incorporación de las medidas acordadas en las estrategias y planes, el aumento en la capacidad de los residentes, la resolución de conflictos y la aclaración de las funciones y responsabilidades. Sobre la base de este ejemplo, en futuros proyectos gubernamentales se podrían utilizar los enfoques basados en el paisaje.

\section{RÉSUMÉ}

Les approches paysager de la conservation visent à résoudre les conflits, à lutter contre la pénurie des surfaces cultivables et des ressources naturelles, et à répondre aux problèmes de concurrence. Souvent guidé par 10 principes, de nombreux exemples d'approche paysagère existent sur le terrain mais peu sont documentés. En conséquence, il s'avère difficile d'évaluer leur mise en œuvre. Le présent article fournit l'exemple d'une mise en oeuvre d'approche paysagère au sein d'un paysage qui comprends des aires protégées. Nous examinons de quelle manière les principes sont utilisés dans le processus de réalisation d'une approche paysagère au sein du paysage de Agoro-Agu dans la région d'Acholi Est en Ouganda. Quels sont les défis et les opportunités liés à cet approche ? Nous constatons que certains principes ont été essentiels pour guider le processus, tandis que d'autres résultaient de l'approche même. Parmi les défis, mentionnons l'insuffisance des données, les difficultés à traiter plusieurs unités de planification, les ressources limitées pour mettre en place des ateliers multipartites et la politisation de certaines questions. Les opportunités comprenaient l'intégration des stratégies et des plans dans les actions, l'augmentation de la capacité résidentielle, la résolution des conflits et la clarification des rôles et des responsabilités. Sur la base de cet exemple, des approches paysagères pourront être utilisées lors de futurs projets gouvernementaux. 